medRxiv preprint doi: https://doi.org/10.1101/2020.06.15.20132290; this version posted June 17, 2020. The copyright holder for this preprint (which was not certified by peer review) is the author/funder, who has granted medRxiv a license to display the preprint in perpetuity. It is made available under a CC-BY-NC-ND 4.0 International license .

\title{
Variable association of atypical femur fracture and osteonecrosis of jaw with bisphosphonates and denosumab use: Drug-safety surveillance study
}

Tigran Makunts ${ }^{1,2}$, Lara S. Anwar ${ }^{1}$, Ruben Abagyan ${ }^{1 *}$

${ }^{1}$ University of California San Diego, Skaggs School of Pharmacy and Pharmaceutical Sciences, San Diego, California, United States

${ }^{2}$ Oak Ridge Institute of Science and Education Fellowship, Center for Drug Evaluation and Research, United States Food and Drug Administration, Silver Spring, Maryland, United States

* Corresponding author (RA) e-mail: rabagyan@health.ucsd.edu

\section{Key points}

1) We performed a disproportionality analysis of over 230,000 post-marketing reports of patients treated for osteoporosis to measure the risk of developing atypical femur fracture (AFF) and osteonecrosis of the jaw (ONJ).

2) Alendronate, ibandronate, risedronate, zoledronic acid, and denosumab were all significantly associated with AFF and ONJ when compared to teriparatide.

3) When compared to denosumab, patients taking alendronate, ibandronate, risedronate, or zoledronic acid had a variable risk of ONJ and AFF, which correlated with the frequency of drug administration. The trend in variable risk was observed in both females and males. 
medRxiv preprint doi: https://doi.org/10.1101/2020.06.15.20132290; this version posted June 17, 2020. The copyright holder for this preprint (which was not certified by peer review) is the author/funder, who has granted medRxiv a license to display the preprint in perpetuity. It is made available under a CC-BY-NC-ND 4.0 International license .

\section{Abstract}

In the United States, there are over ten million adults diagnosed with osteoporosis and many more are at risk of developing the condition. Osteoporosis affects both males and females, mostly post-menopausal. Bisphosphonates and denosumab have been widely used globally to treat the condition. The use of bisphosphonates and denosumab had been associated with rare adverse effects including osteonecrosis of the jaw, ONJ, and atypical femur fracture, AFF. However, it remained unclear whether those side effects were class-wide or drug-specific. By analyzing over 230,000 osteoporosis patient reports from the FDA adverse event reporting system, FAERS, we confirmed the association of bisphosphonates and denosumab use with AFF and ONJ.

Additionally, comparing each of the four frequently used bisphosphonates with denosumab-treated patients used as a control, we identified: (i) varying significance of association with ONJ and AFF for alendronate, risedronate, ibandronate and zoledronic acid, (ii) over two fold increase in risk of both side effects in alendronate patients, particularly in females, (iii) over a six fold increase in AFF risk in both males and females taking risedronate, and (iv) lower risk of both AFF and ONJ, for zoledronic acid patients compared to denosumab.

\section{Introduction}

The National Osteoporosis Foundation reports that 10.2 million adults age fifty and older had osteoporosis in the U.S in 2013, and 43.4 million adults were at risk of developing the disease, giving a total of about 54 million U.S. adults with osteoporosis or low bone mass[1]. It was projected that this total number will grow to 64.4 million by 2020 and to 
medRxiv preprint doi: https://doi.org/10.1101/2020.06.15.20132290; this version posted June 17, 2020. The copyright holder for this preprint (which was not certified by peer review) is the author/funder, who has granted medRxiv a license to display the preprint in perpetuity. It is made available under a CC-BY-NC-ND 4.0 International license .

71.2 million by 2030[1]. Moreover, the study showed that more women than men had osteoporosis (8.2 million vs. 2.0 million) and low bone mass (27.3 million vs. 16.1 million)[1]. Osteoporosis causes a reduction of bone mass and strength due to multiple pathogenic mechanisms, leading to increased bone fragility and susceptibility to breakage[2, 3].

Three main types of drugs are recommended for the treatment of osteoporosis, including bisphosphonates (alendronate, risedronate, ibandronate, and zoledronic acid), denosumab and teriparatide[4]. Bisphosphonates are small molecules that bind to hydroxyapatite in bone, leading to the inhibition of osteoclastic bone resorption[5, 6], denosumab is a fully humanized monoclonal antibody to RANKL[7], and teriparatide is a synthetic version of the human parathyroid hormone which works by activating osteoblasts[8, 9].

Common adverse effects of oral bisphosphonates (alendronate, risedronate, ibandronate) include, but not limited to, upper gastrointestinal side effects (acid reflux, esophagitis, ulcers) due to local effects on esophagus and/or gastric mucosa[10-12]. Intravenous (IV) bisphosphonates (ibandronate, zoledronic acid) are associated with injection-related reactions, such as, flu-like symptoms (fever, myalgias, arthralgias)[12, 13]. Musculoskeletal pain is common to both oral and IV formulations[10-13]. Denosumab, administered as a subcutaneous injection, is associated with fatigue/asthenia, hypophosphatemia, nausea, and back pain[14]. Common side effects of teriparatide include injection-site pain, nausea, headaches, leg cramps, and dizziness[15]. 
medRxiv preprint doi: https://doi.org/10.1101/2020.06.15.20132290; this version posted June 17, 2020. The copyright holder for this preprint (which was not certified by peer review) is the author/funder, who has granted medRxiv a license to display the preprint in perpetuity. It is made available under a CC-BY-NC-ND 4.0 International license .

While these adverse effects are expected and can be managed, there are two counterintuitive and troubling adverse effects, unique to bisphosphonates and denosumab, that directly damage the bone instead of preventing bone loss: 1) osteonecrosis of the jaw (ONJ), and 2) atypical femur fracture (AFF)[16].

AFF is referred to as "atypical" due to the location of the fracture. AFF occurs in the subtrochanteric or diaphyseal region of the femur with simple transverse or oblique pattern[16]. The pathophysiology of AFF is not well understood. However, it is suggested that since bisphosphonates inhibit the activity of osteoclasts, they cause suppression of bone turnover rate, resulting in the effects that contribute to AFF, such as accumulation of microdamage in the bone[16]. Similarly, denosumab provokes the disruption of the targeted remodeling process, which is needed to replace microcracks with new bone tissue, leading to accumulation of bone microdamage[17]. A study done by Black and colleagues reviewed 284 records of hip or femur fractures associated with bisphosphonates use among 14,195 women in these trials[18]. The study showed no significant increase in the risk of AFF for alendronate use (relative risk (RR) 1.03, 95\% confidence interval $(\mathrm{Cl})[0.06-16.46])$ and for zoledronic acid use $(\mathrm{RR} 1.50,95 \% \mathrm{Cl}$ [0.25-9.00]) compared to placebo[18]. However, many case reports and small-scale studies have shown the association of bisphosphonate use with AFF for alendronate, ibandronate, risedronate, zoledronic acid, and denosumab[19-27].

$\mathrm{ONJ}$ is a severe disease that affects the jaw, and it is defined as exposed, necrotic bone in the maxillary and mandibular regions[28]. There are multiple factors that play a role in the pathophysiology of ONJ, putting the oral cavity at a higher risk[29]. Oral structures can be subjected to various types of stresses such as mastication, dental procedures, 
medRxiv preprint doi: https://doi.org/10.1101/2020.06.15.20132290; this version posted June 17, 2020. The copyright holder for this preprint (which was not certified by peer review) is the author/funder, who has granted medRxiv a license to display the preprint in perpetuity. It is made available under a CC-BY-NC-ND 4.0 International license .

periodontal disease, caries, poor oral hygiene and effects of chemotherapy[29]. Combination of these factors can lead to bone exposure and demand higher rates of bone remodeling[29]. It is advised for all patients to undergo dental examination prior to initiating treatment with bisphosphonates or denosumab, as well as, maintaining good oral hygiene throughout the treatment[30].

A literature review of eleven publications reporting 26 cases of ONJ was performed by Pazianas and colleagues to clarify the association between bisphosphonate use and the development of such adverse event[31]. The study showed that the relative prevalence of ONJ was low and more often associated with a dental procedure; however, the authors did not draw any conclusion related to the differences between the drugs due to the scarcity of the reports[31]. There have been a few case reports and small-scale studies on the ONJ ADR in patients taking alendronate, ibandronate, risedronate, zoledronic acid, and denosumab[32-37].

To further quantify the drug-specific associations those treatments with AFF and ONJ and expand on current evidence we analyzed over twelve million post-marketing adverse drug reaction reports. Initially, we illustrated the association of ONJ and AFF with bisphosphonates and denosumab in relation to teriparatide. Teriparatide was chosen due to its unique mechanism of action and $\mathrm{AE}$ profile [38-40].

Additionally, we evaluated the reporting odds ratios (RORs) of AFF and ONJ in patients with osteoporosis for each of four bisphosphonates using denosumab as a control and evaluated the co-occurrence of these AEs. The magnitude of the effects, and their $95 \%$ confidence intervals (Cls) were also evaluated for each bisphosphonate in both male and female patients to quantify additional risk factors. 
medRxiv preprint doi: https://doi.org/10.1101/2020.06.15.20132290; this version posted June 17, 2020. The copyright holder for this preprint (which was not certified by peer review) is the author/funder, who has granted medRxiv a license to display the preprint in perpetuity. It is made available under a CC-BY-NC-ND 4.0 International license.

6

\section{Methods}

FAERS/AERS contains reports of medication-related adverse effects submitted to the FDA voluntarily by patients, healthcare providers, and legal representatives through MedWatch[41], the FDA Safety Information and Adverse Event Reporting System. FAERS reports were utilized to conduct a retrospective analysis on patients with osteoporosis, taking either bisphosphonates, denosumab, or teriparatide to compare the frequency of rare adverse events, AFF and ONJ, associated with the use of these drugs.

Data sets are available to the public online at:

http://www.fda.gov/Drugs/GuidanceComplianceRegulatorylnformation/Surveillance/Adv erseDrugEffects/ucm082193.htm.

Normalizing and combining the data

Each quarterly report set was then downloaded in a (.TXT) format and modified to produce a standardized table field structure. Some data sets contained missing columns, and blank columns were added with no values to homogenize the reports[42, 43]. The final data set contained over twelve million reports. Reports were submitted mostly from the United States, however, many reports were submitted from around the world with their country-specific formats. International brand and generic names were translated into a single generic form using online drug databases[42, 43]. 
medRxiv preprint doi: https://doi.org/10.1101/2020.06.15.20132290; this version posted June 17, 2020. The copyright holder for this preprint (which was not certified by peer review) is the author/funder, who has granted medRxiv a license to display the preprint in perpetuity. It is made available under a CC-BY-NC-ND 4.0 International license .

\section{7}

\section{Choosing the cohorts}

The FAERS system was queried based on the adverse events reported between January of 2004 and March of 2019. A total of 12,004,552 FAERS adverse reaction reports were collected. Reports of patients with osteoporosis were selected into the osteoporosis cohort if the "indication" field in the FAERS reports had the term osteoporosis exclusively. Approximately $0.04 \%$ of FAERS reports are duplicates. These are follow-up reports with the same case numbers. In our case selection, the duplicate reports were excluded. Additionally, reports by lawyers were also excluded due to potential bias.

Guidelines and position statements from the following organizations and societies were used to identify the first-line recommended therapeutics for osteoporosis prevention and treatment: The American Association of Clinical Endocrinologists[44], the Endocrine Society[45], the American Academy of Family Physicians[46], the National Osteoporosis Foundation[47], and the North American Menopause Society[48]. Alendronate, ibandronate, risedronate, zoledronic acid, and denosumab were all recommended as a first-line line therapeutic option.

From 232,512 osteoporosis reports, a total of 133,089 osteoporosis monotherapy reports were selected. Out of the latter osteoporosis group, reports where denosumab was used for the treatment of osteoporosis, excluding bisphosphonates (alendronate, ibandronate, risedronate, zoledronic acid) and other drugs associated with ONJ such as m-TOR inhibitors (sirolimus, everolimus, temsirolimus), and antiangiogenic drugs (bevacizumab, sunitinib, sorafenib, pazopanib, axitinib), were selected into the denosumab cohort $(n=18,336)$. Reports where bisphosphonates were used, excluding 
medRxiv preprint doi: https://doi.org/10.1101/2020.06.15.20132290; this version posted June 17, 2020. The copyright holder for this preprint (which was not certified by peer review) is the author/funder, who has granted medRxiv a license to display the preprint in perpetuity. It is made available under a CC-BY-NC-ND 4.0 International license.

8

denosumab, m-TOR inhibitors, and antiangiogenic drugs, were selected into the bisphosphonates cohort $(n=36,527)$. Out of the osteoporosis reports, reports where teriparatide were used for the treatment of osteoporosis, excluding denosumab, bisphosphonates, m-TOR inhibitors, and antiangiogenic drugs, were selected into the teriparatide cohort $(n=66,173)$. The bisphosphonate cohort was further split into alendronate $(n=14,682)$, ibandronate $(n=6,065)$, risedronate $(n=2,309)$, and zoledronic acid $(n=13,471)$ sub-cohorts (Fig 1). Demographic analysis was also performed (Tables 1 and 2). 
medRxiv preprint doi: https://doi.org/10.1101/2020.06.15.20132290; this version posted June 17, 2020. The copyright holder for this preprint (which was not certified by peer review) is the author/funder, who has granted medRxiv a license to display the preprint in perpetuity.

It is made available under a CC-BY-NC-ND 4.0 International license .

9

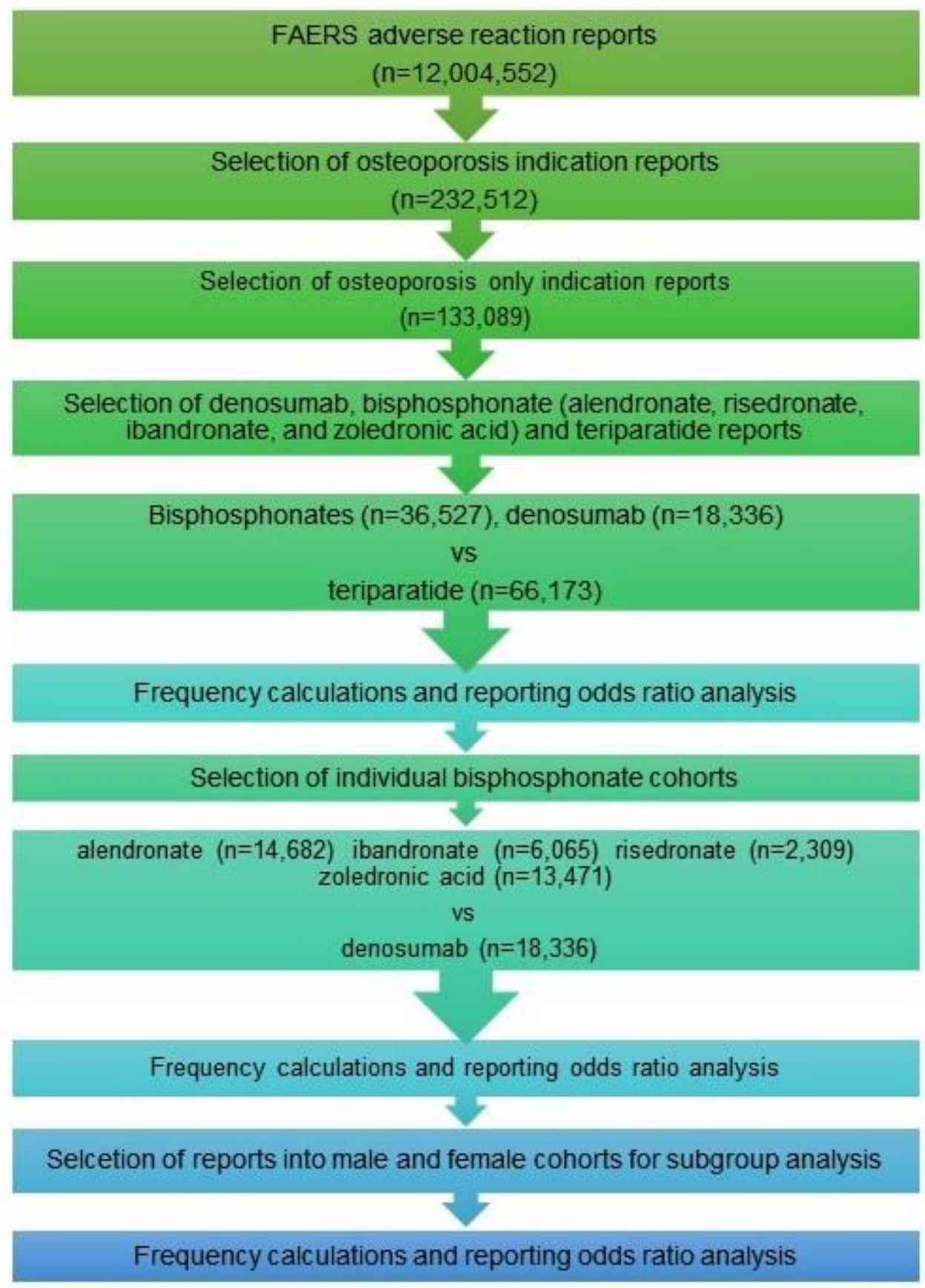

Fig 1. Cohort selection.

Cohort selection for adverse event rate comparison between bisphosphonates, denosumab and teriparatide as a class, and between individual bisphosphonates and denosumab.

Abbreviations: FAERS - FDA Adverse Event Reporting System, 
medRxiv preprint doi: https://doi.org/10.1101/2020.06.15.20132290; this version posted June 17, 2020. The copyright holder for this preprint (which was not certified by peer review) is the author/funder, who has granted medRxiv a license to display the preprint in perpetuity. It is made available under a CC-BY-NC-ND 4.0 International license .

10

Table 1. Patient demographics in bisphosphonates and denosumab cohorts

\begin{tabular}{|c|r|r|r|r|r|}
\hline Sex & $\begin{array}{r}\text { Bisphosphonates } \\
(\mathbf{n = 3 6 , 5 2 7 )}\end{array}$ & $\begin{array}{r}\text { Frequency } \\
(\%)\end{array}$ & $\begin{array}{r}\text { Denosumab } \\
(\mathrm{n}=\mathbf{1 8 , 3 3 6 )})\end{array}$ & $\begin{array}{r}\text { Frequency } \\
(\%)\end{array}$ & $\begin{array}{r}\text { \% Difference } \\
\hline \text { Female }\end{array}$ \\
\hline Male & 30,154 & 82.55 & 15,146 & 82.60 & 0.05 \\
\hline Unknown & 3,303 & 9.04 & 2,009 & 10.96 & 1.92 \\
\hline
\end{tabular}

Table 2. Age difference in patients with osteoporosis taking bisphosphonates vs. denosumab

\begin{tabular}{|c|r|r|}
\hline & Bisphosphonates & Denosumab \\
\hline Mean Age, Years (SD) & $69.10(12.22)$ & $73.01(11.52)$ \\
\hline Median Age, Years & 69.40 & 67.60 \\
\hline Unknown (\%) & 32.60 & 25.98 \\
\hline
\end{tabular}

$\underline{\text { Statistical analysis }}$

Descriptive statistics:

Reporting frequencies for ONJ and AFF ADRs were calculated by the equation: 
medRxiv preprint doi: https://doi.org/10.1101/2020.06.15.20132290; this version posted June 17, 2020. The copyright holder for this preprint (which was not certified by peer review) is the author/funder, who has granted medRxiv a license to display the preprint in perpetuity. It is made available under a CC-BY-NC-ND 4.0 International license.

11

Frequency $=($ Number of reports with ADR of interest)/(Number of total ADR reports $) * 100$

Comparative Statistics:

The analysis was performed and presented according to established guidelines of pharmacovigilance research established by the FDA and the scientific community. Disproportionality analysis term Reporting Odds Ratio (ROR) was used to differentiate the study from other observational epidemiological studies[49-51].

ADR report rates were compared via the ROR analysis for Figures 1-6 using the following equations:

$$
\mathrm{ROR}=(\mathrm{a} / \mathrm{b}) /(\mathrm{c} / \mathrm{d})
$$

Where:

a: ONJ/AFF cases in exposed group with an $\mathrm{AE}$ b: ONJ/AFF cases in exposed group with no $\mathrm{AE}$ c: ONJ/AFF cases in control group with the $\mathrm{AE}$ d: ONJ/AFF cases in control group with no $A E$

$$
\text { LnROR=Ln(ROR) }
$$

Standard Error of Log Reporting Odds Ratio;

$$
\text { SELnROR }=\sqrt{ }(1 / a+1 / b+1 / c+1 / d)
$$


medRxiv preprint doi: https://doi.org/10.1101/2020.06.15.20132290; this version posted June 17, 2020. The copyright holder for this preprint (which was not certified by peer review) is the author/funder, who has granted medRxiv a license to display the preprint in perpetuity. It is made available under a CC-BY-NC-ND 4.0 International license.

12

95\% Confidence Interval;

$95 \% \mathrm{Cl}=[\exp (\operatorname{LnROR}-1.96 \times S E L n R O R), \exp (\operatorname{LnROR}+1.96 \times S E L n R O R)]$

\section{Results}

Osteonecrosis of the jaw (ONJ)

Patients with osteoporosis-only indication who used bisphosphonates or denosumab had an about hundred-fold higher frequency of ONJ when compared to teriparatide, (reporting odds ratio, ROR, 128.68, 95\% confidence interval $(\mathrm{Cl})[84.45,196.06])$ and (108.74 [71.07, 166.39]) respectively (Fig 2a,2b). 
medRxiv preprint doi: https://doi.org/10.1101/2020.06.15.20132290; this version posted June 17, 2020. The copyright holder for this preprint (which was not certified by peer review) is the author/funder, who has granted medRxiv a license to display the preprint in perpetuity. It is made available under a CC-BY-NC-ND 4.0 International license .

13

a

\section{Frequency of osteonecrosis of jaw (ONJ) reports in patients with osteoporosis in bishosphonate, denosumab, and teriparatide cohorts}

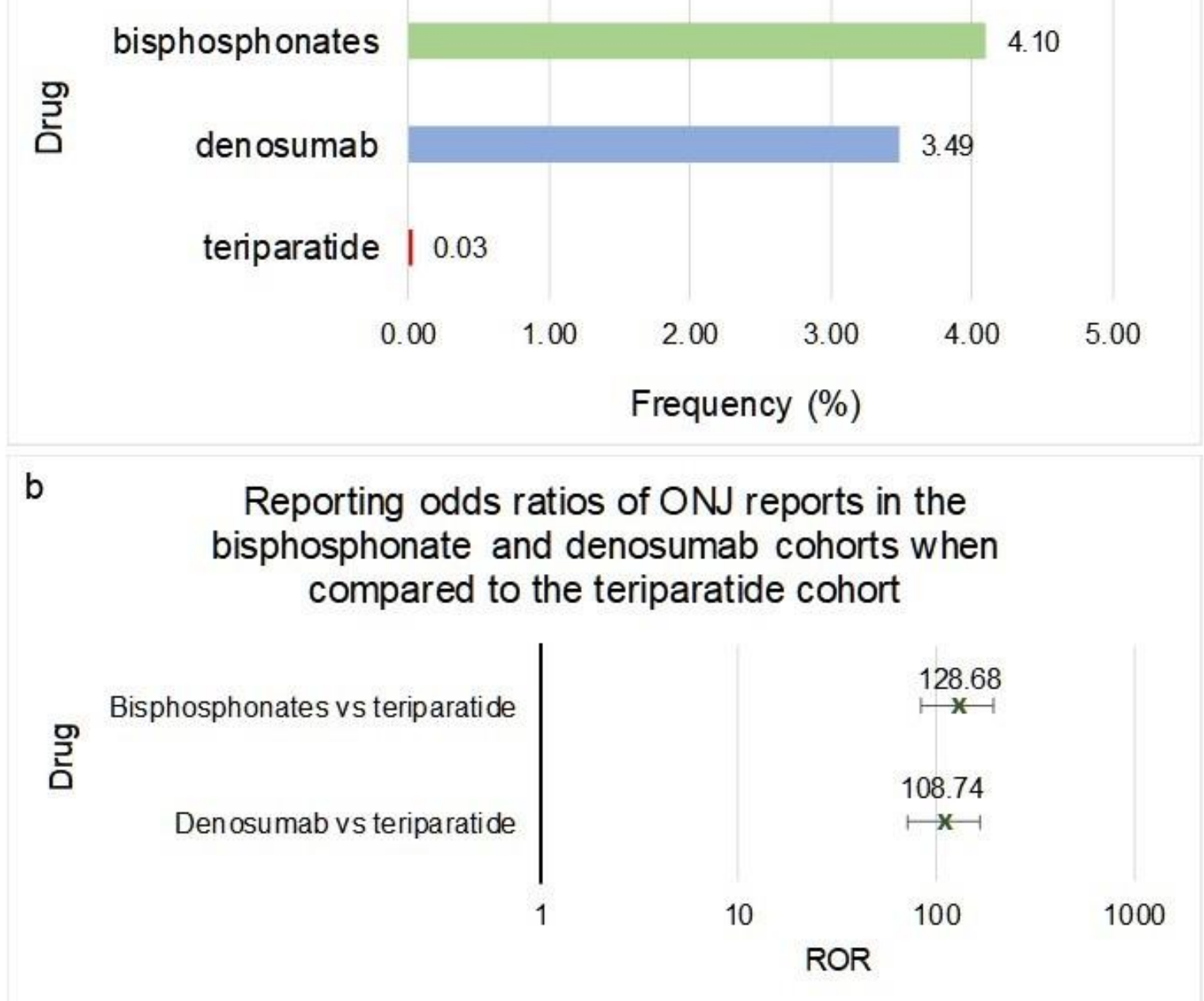

Fig 2. Frequencies and reporting odds ratios (RORs) of osteonecrosis of the jaw

(ONJ) adverse events in bisphosphonates, denosumab and teriparatide cohorts. (a)

Frequencies of ONJ for patients in FAERS who took bisphosphonates as a class ( $n=36,527)$, denosumab $(n=18,336)$ or teriparatide $(n=66,173)$. (b) Reporting odds ratios were calculated comparing adverse event frequencies of bisphosphonates, denosumab and teriparatide patients. Ranges represent $95 \%$ confidence intervals (95\% Cl) (see Methods). X-axis is presented in log scale. Abbreviations: ONJ - osteonecrosis of jaw, ROR - reporting odds ratio. 
medRxiv preprint doi: https://doi.org/10.1101/2020.06.15.20132290; this version posted June 17, 2020. The copyright holder for this preprint (which was not certified by peer review) is the author/funder, who has granted medRxiv a license to display the preprint in perpetuity. It is made available under a CC-BY-NC-ND 4.0 International license.

14

While in teriparatide comparison the $95 \% \mathrm{CI}$ ROR ranges of denosumab and bisphosphonate-class overlapped, bisphosphonates as a class, when compared directly with denosumab, had a significantly higher risk of ONJ $(1.18[1.08,1.30])$ (Fig 3a and 3b). However individual bisphosphonate drugs varied in the ONJ RORs vs denosumab. Interestingly, the alendronate cohort had a two-fold increase in risk of ONJ when compared to denosumab $(2.00[1.84,2.26])$ (Fig 3a,3b). On the other hand, ibandronate and zoledronic acid cohorts had significantly lower frequencies of ONJ when compared to denosumab, $(0.52[0.43,0.65])$ and $(0.61[0.53,0.70])$ respectively (Fig 3a,3b). The difference in the frequency of ONJ in patients with osteoporosis taking risedronate did not meet the significance criteria when compared to denosumab $(1.06[0.84,1.33])$ (Fig $3 a, 3 b)$. 
medRxiv preprint doi: https://doi.org/10.1101/2020.06.15.20132290; this version posted June 17, 2020. The copyright holder for this preprint (which was not certified by peer review) is the author/funder, who has granted medRxiv a license to display the preprint in perpetuity.

It is made available under a CC-BY-NC-ND 4.0 International license .

15

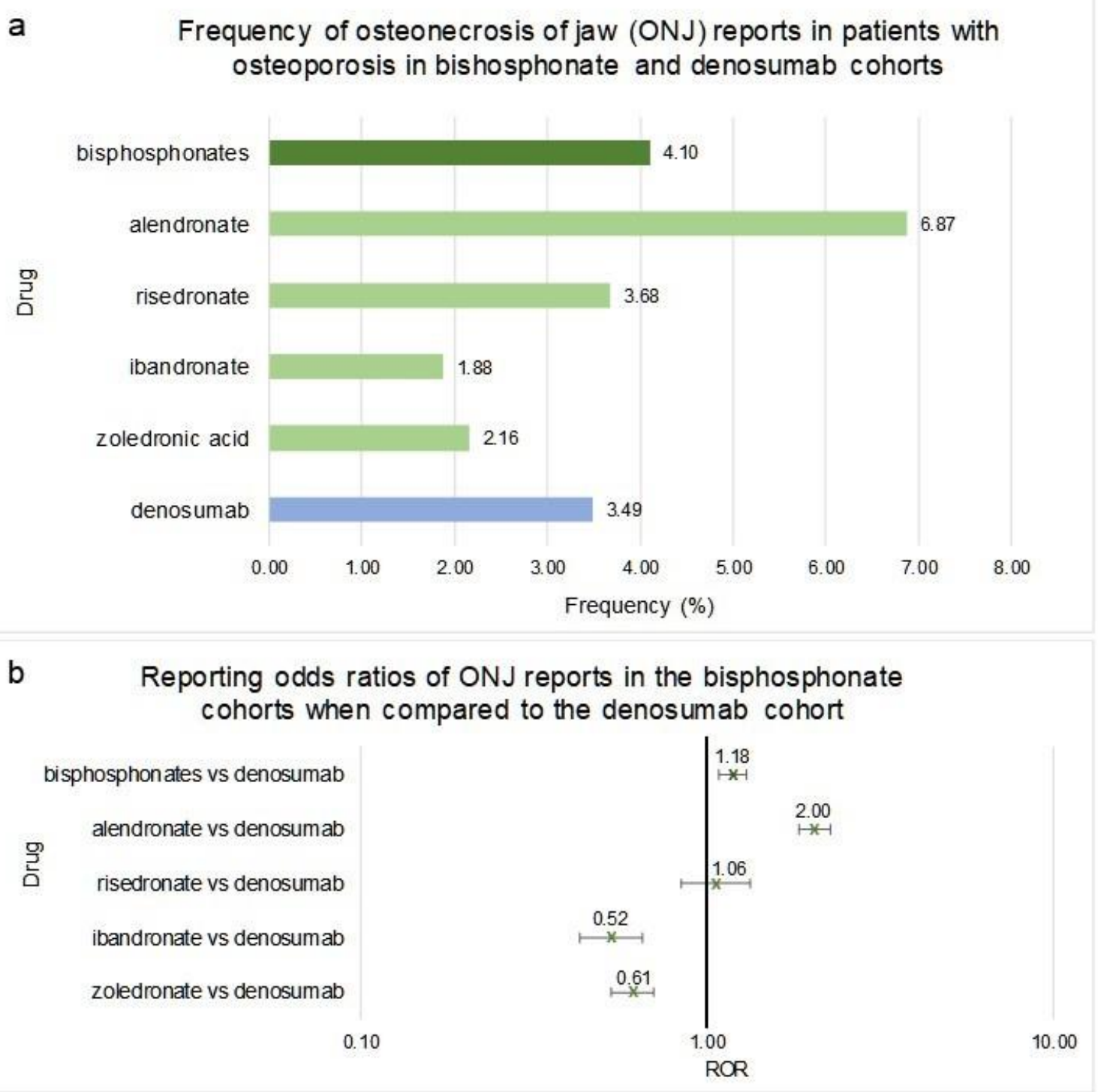

Fig 3. Frequencies and reporting odds ratios (RORs) of osteonecrosis of the jaw (ONJ) adverse events in patients with osteoporosis taking bisphosphonates or denosumab. (a) Frequencies of ONJ for patients in FAERS who took bisphosphonates as a class $(n=36,527)$, individual bisphosphonates: alendronate $(n=14,682)$, ibandronate $(n=6,065)$, risedronate ( $n=2,309)$, zoledronic acid $(n=13,471)$, or denosumab $(n=18,336)$. (b) Reporting odds ratios were calculated comparing adverse event frequencies of bisphosphonates and denosumab patients. Ranges represent 95\% confidence intervals (95\% Cl) (see Methods). X-axis is presented in log scale. Abbreviations: ONJ - osteonecrosis of jaw, ROR - reporting odds ratio. 
medRxiv preprint doi: https://doi.org/10.1101/2020.06.15.20132290; this version posted June 17, 2020. The copyright holder for this preprint (which was not certified by peer review) is the author/funder, who has granted medRxiv a license to display the preprint in perpetuity. It is made available under a CC-BY-NC-ND 4.0 International license.

16

Females who used bisphosphonates as a class or alendronate, as an individual bisphosphonate, had a significant increase in the relative reporting odds ratio of ONJ when compared to denosumab $(1.20[1.10,1.33])$ and $(2.10[1.84,2.30$ respectively (Fig 4a,4b). The ibandronate and zoledronic acid cohorts had significantly lower risk of ONJ compared to denosumab $(0.55[0.44,0.67])$ and $(0.66[0.57,0.76])$ respectively (Fig $4 a, 4 b)$.

Males who used bisphosphonates as a class, ibandronate, risedronate or zoledronic acid had no significant difference in the reporting frequency of ONJ when compared to denosumab $(1.28[0.92,1.76]),(0.42[0.14,1.15]),(1.48[0.66,3.30])$ and $(0.80[0.53$, 1.23]) respectively (Fig 4c, 4d). Similar to females, alendronate male cohort had a significantly higher occurrence and related odds ratio of ONJ when compared to denosumab (2.13 [1.50, 3.04]) (Fig 4c, 4d). 
medRxiv preprint doi: https://doi.org/10.1101/2020.06.15.20132290; this version posted June 17, 2020. The copyright holder for this preprint (which was not certified by peer review) is the author/funder, who has granted medRxiv a license to display the preprint in perpetuity.

It is made available under a CC-BY-NC-ND 4.0 International license .

17

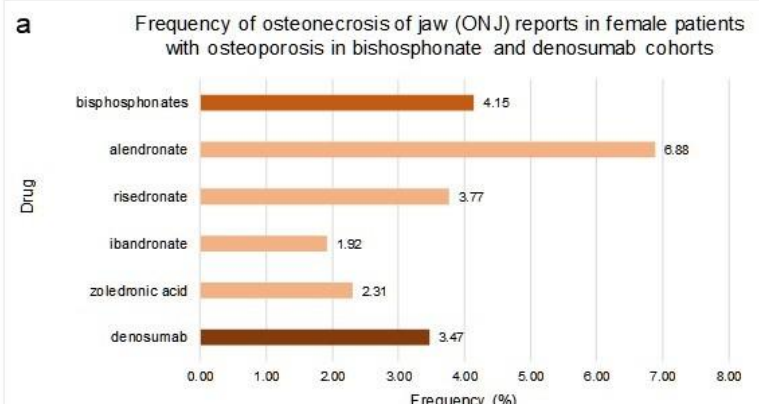

C Frequency of osteonecrosis of jaw $(\mathrm{ONJ})$ reports in male patients with osteoporosis in bishosphonate and denosumab cohorts
wh
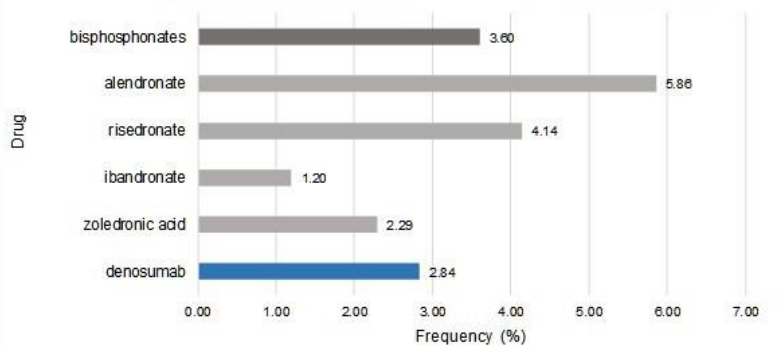

b Reporting odds ratios of ONJ reports in the bisphosphonate female cohorts when compared to the female denosumab cohort
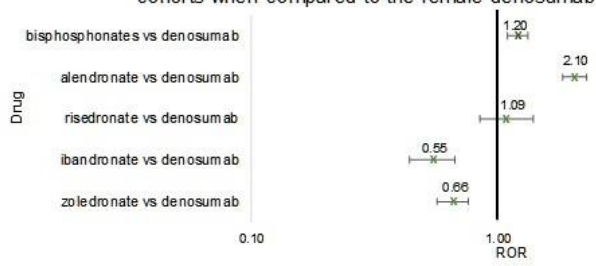

d

Reporting odds ratios of ONJ reports in the male bisphosphonate cohorts when compared to the male denosumab cohort

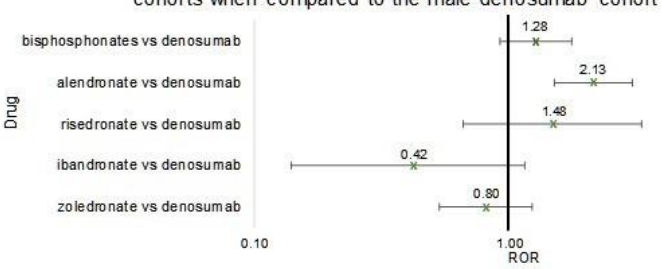

Fig 4. Frequencies and reporting odds ratios (RORs) of osteonecrosis of the jaw (ONJ) in female and male patients with osteoporosis taking bisphosphonates or denosumab. (a) frequencies of ONJ for female patients in FAERS who took bisphosphonates as a class $(n=31,834)$, alendronate $(n=12,614)$, ibandronate $(n=5,614)$, risedronate $(n=2,016)$, zoledronic acid $(n=11,590)$ or denosumab $(n=15,690)$. (b) Reporting odds ratios were calculated comparing adverse event frequencies females taking bisphosphonates or denosumab. (c) frequencies of ONJ for male patients in FAERS who took bisphosphonates as a class $(n=3,303)$, alendronate $(n=1,229)$, ibandronate $(n=334)$, risedronate $(n=169)$, zoledronic acid $(n=1,571)$ or denosumab $(n=2,009)$. (d) Reporting odds ratios were calculated comparing adverse event frequencies females taking bisphosphonates or denosumab. Ranges represent $95 \%$ confidence intervals $(95 \% \mathrm{Cl})$ (see Methods). X-axis is presented in log scale. Abbreviations: ONJ - osteonecrosis of jaw, ROR - reporting odds ratio. 
medRxiv preprint doi: https://doi.org/10.1101/2020.06.15.20132290; this version posted June 17, 2020. The copyright holder for this preprint (which was not certified by peer review) is the author/funder, who has granted medRxiv a license to display the preprint in perpetuity. It is made available under a CC-BY-NC-ND 4.0 International license.

18

Atypical femur fracture (AFF)

Patients who used bisphosphonates or denosumab had a significantly higher frequency of AFF when compared to teriparatide. The reporting odds ratio, ROR, for bisphosphonates was 97.16, with 95\% confidence interval, $\mathrm{Cl}$, [43.32, 217.92]), and for denosumab it was $51.97[22.71,118.91]$ (Fig 5a,5b).

a

\section{Frequency of atypical femur fracture (AFF) reports in} patients with osteoporosis in bisphosphonate, denosumab, and teriparatide cohorts

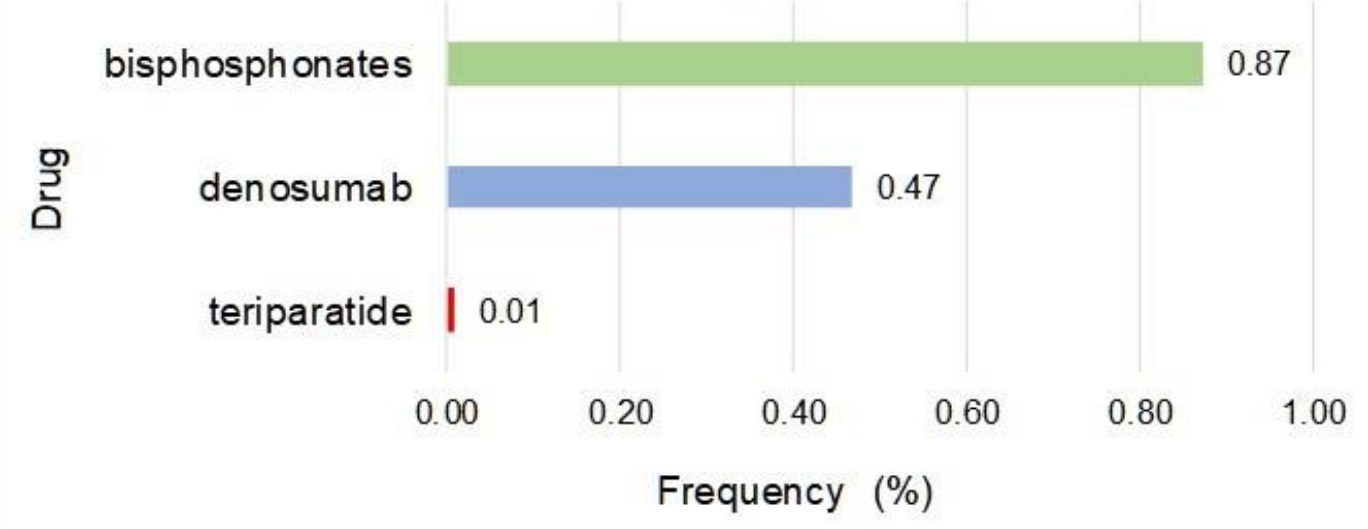

b

Reporting odds ratios of AFF reports in the bisphosphonate and denosumab cohorts when compared to the teriparatide cohort

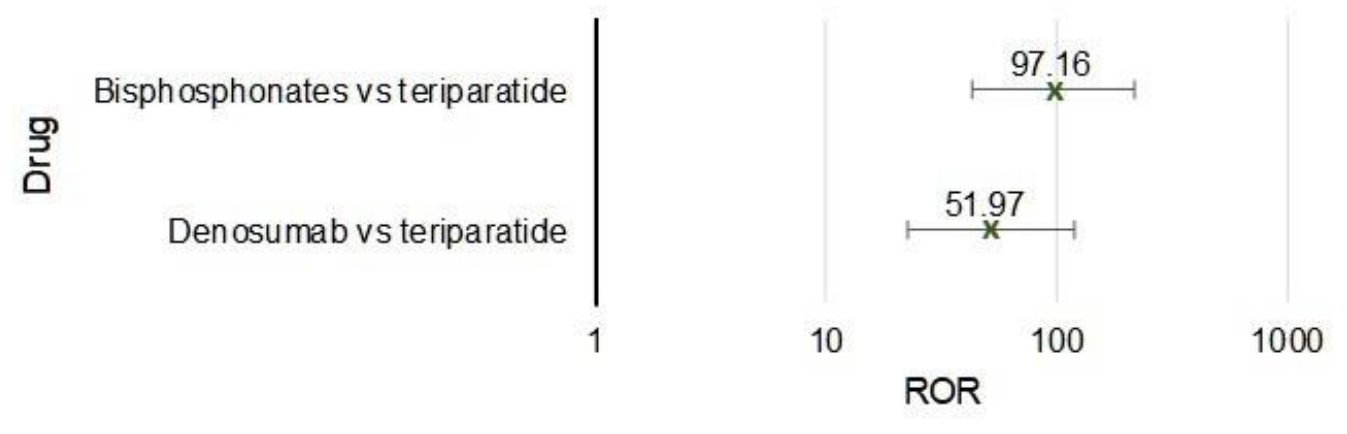

Fig 5. Frequencies and reporting odds ratios (RORs) of atypical femur fracture (AFF) adverse events in bisphosphonates, denosumab and teriparatide cohorts. (a) Frequencies of ONJ for patients in FAERS who took bisphosphonates as a class ( $n=36,527)$, denosumab 
medRxiv preprint doi: https://doi.org/10.1101/2020.06.15.20132290; this version posted June 17, 2020. The copyright holder for this preprint (which was not certified by peer review) is the author/funder, who has granted medRxiv a license to display the preprint in perpetuity. It is made available under a CC-BY-NC-ND 4.0 International license.

19

( $n=18,336)$ or teriparatide $(n=66,173)$. (b) Reporting odds ratios were calculated comparing adverse event frequencies of bisphosphonates, denosumab and teriparatide patients. Ranges represent $95 \%$ confidence intervals $(95 \% \mathrm{Cl}$ ) (see Methods). X-axis is presented in log scale. Abbreviations: AFF - atypical femur fracture, ROR - reporting odds ratio.

When compared to denosumab, patients taking bisphosphonates had a significant increase in the frequency of AFF (1.87 [1.47, 2.37]) (Fig 6a,6b). However, the adverse effects between the four bisphosphonates under study differed significantly. The risedronate and alendronate cohorts had significantly higher ROR values of AFF than that of denosumab $(6.63[4.82,9.12])$ and $(3.03[2.36,3.91])$ respectively (Fig 6a,6b). The zoledronic acid cohort had a significantly lower AFF RORs when compared to denosumab, $(0.29[0.18,0.49])$ (Fig 6a,6b). There was no significant difference in the reported frequencies of AFF in patients taking ibandronate when compared to denosumab $(\mathrm{ROR}=0.80[0.51,1.28])($ Fig 6a,6b) 
medRxiv preprint doi: https://doi.org/10.1101/2020.06.15.20132290; this version posted June 17, 2020. The copyright holder for this preprint (which was not certified by peer review) is the author/funder, who has granted medRxiv a license to display the preprint in perpetuity.

It is made available under a CC-BY-NC-ND 4.0 International license .

20

a Frequency of atypical femur fracture (AFF) reports in patients with osteoporosis in bisphosphonate and denosumab cohorts

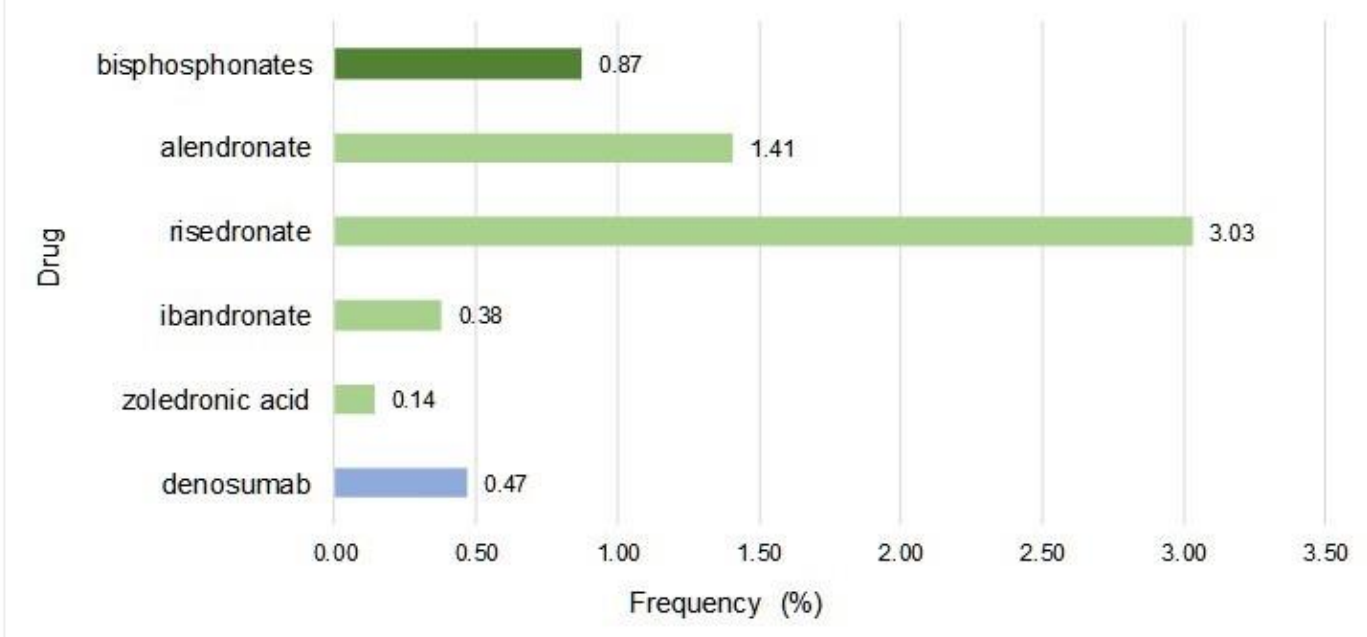

b Reporting odds ratios of AFF reports in the bisphosphonate cohorts when compared to the denosumab cohort

\begin{abstract}
bisphosphonates denosumab
alendronate vs denosumab

온 risedronate vs denosumab

ibandronate vs denosumab

zoledronate vs denosumab
\end{abstract}

0.10

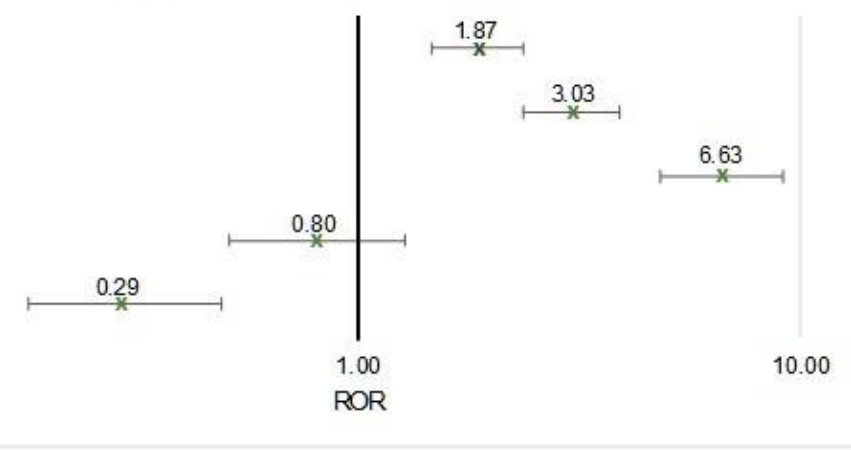

Fig 6. Frequencies and reporting odds ratios (RORs) of atypical femur fracture (AFF) adverse events in patients with osteoporosis taking bisphosphonates or denosumab. (a)

Frequencies of ONJ for patients in FAERS who took bisphosphonates as a class $(n=36,527)$, individual bisphosphonates: alendronate $(n=14,682)$, ibandronate $(n=6,065)$, risedronate ( $n=2,309)$, zoledronic acid $(n=13,471)$, or denosumab $(n=18,336)$. (b) Reporting odds ratios were calculated comparing adverse event frequencies of bisphosphonates and denosumab patients. Ranges represent $95 \%$ confidence intervals $(95 \% \mathrm{Cl})$ (see Methods). X-axis is presented in log scale. Abbreviations: AFF - atypical femur fracture, ROR - reporting odds ratio. 
medRxiv preprint doi: https://doi.org/10.1101/2020.06.15.20132290; this version posted June 17, 2020. The copyright holder for this preprint (which was not certified by peer review) is the author/funder, who has granted medRxiv a license to display the preprint in perpetuity. It is made available under a CC-BY-NC-ND 4.0 International license .

21

Females who used bisphosphonates as a class, alendronate, or risedronate had a significant increase in the frequency of AFF when compared to denosumab (1.83 $[1.47,2.44]),(3.11[2.38,4.10])$ and $(6.58[4.70,9.21])$ respectively (Fig 7a,7b). The zoledronic acid cohort had a significantly lower frequency of AFF when compared to denosumab (ROR=0.28 $[0.17,0.49])$ (Fig 7a, 7b). The ROR value of AFF in female ibandronate patients did not meet the significance criteria when compared to denosumab since the range covered the value of $1(0.84[0.53,1.35])$ (Fig 7a, 7b). Males who used bisphosphonates as a class, alendronate, or zoledronic acid had no significant difference in the AFF RORs when compared to denosumab (1.13 [0.48, $2.68]),(1.43[0.52,3.96])$, and $(0.47[0.13,1.81])$ respectively (Fig 7c, 7d). The risedronate cohort had a significantly higher AFF ROR when compared to denosumab $(6.63[4.82,9.12])$ (Fig 7c, 7d). There were no reports of AFF in male patients taking ibandronate for osteoporosis.

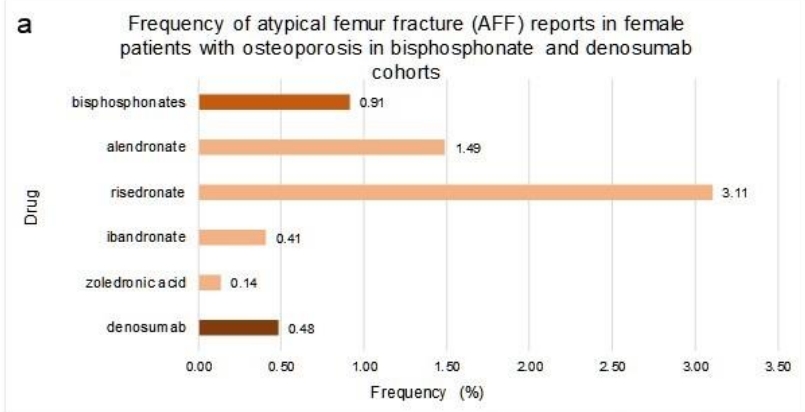

b Reporting odds ratios of AFF reports in the bisphosphonate female cohorts when compared to the female denosumab cohort

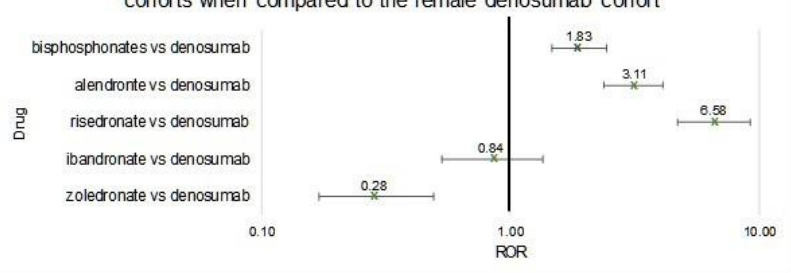

c Frequency of atypical femur fracture (AFF) reports in male patients with osteoporosis in bisphosphonate and denosumab cohorts

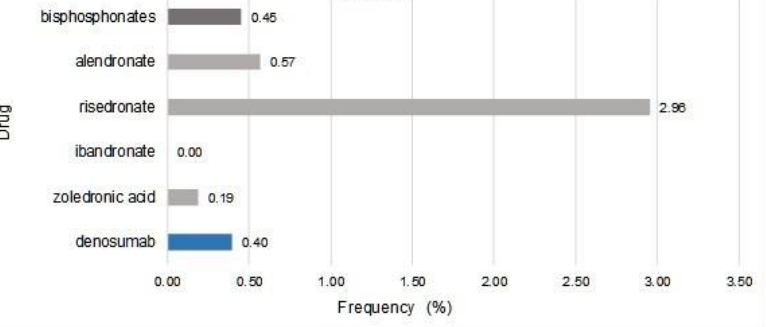

d Reporting odds ratios of AFF reports in the male bisphosphonate cohorts when compared to the male denosumab cohort

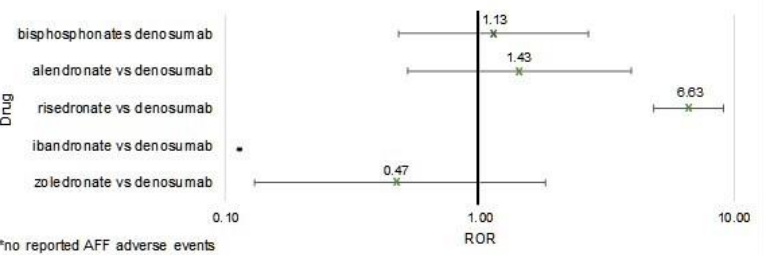


medRxiv preprint doi: https://doi.org/10.1101/2020.06.15.20132290; this version posted June 17, 2020. The copyright holder for this preprint (which was not certified by peer review) is the author/funder, who has granted medRxiv a license to display the preprint in perpetuity. It is made available under a CC-BY-NC-ND 4.0 International license .

22

Fig 7. Frequencies and reporting odds ratios (RORs) of atypical femur fracture (AFF) in female and male patients with osteoporosis taking bisphosphonates or denosumab. (a) frequencies of AFF for female patients in FAERS who took bisphosphonates as a class $(n=31,879)$, alendronate $(n=12,614)$, ibandronate $(n=5,614)$, risedronate $(2,016)$, zoledronic acid $(n=11,590)$ or denosumab $(n=15,690)$. (b) were calculated comparing adverse event frequencies females taking bisphosphonates or denosumab. (c) frequencies of AFF for male patients in FAERS who took bisphosphonates as a class $(n=3,303)$, alendronate $(n=1,229)$, ibandronate $(n=334)$, risedronate $(n=169)$, zoledronic acid $(n=1,571)$ or denosumab $(n=2,009)$.

(d) RORs were calculated comparing adverse event frequencies females taking bisphosphonates or denosumab. Ranges represent 95\% confidence intervals $(95 \% \mathrm{Cl}$ ) (see Methods). X-axis is presented in log scale. Abbreviations: AFF - atypical femur fracture, ROR reporting odds ratio.

In a separate analysis we investigated the most common AEs reported alongside AFF and ONJ and observed that: 1) AFF and ONJ co-occurrence was extremely rare and was reported only in 3 out of 18,336 denosumab reports (Supplement Table S1); 2) ONJ co-occurred primarily with dental health and procedure complications, and; 3) AFF most often co-occurred with falls and bone health related AEs (Supplement Table S2).

\section{Discussion}

In this study we quantified the association between individual bisphosphonate use and AFF and ONJ adverse events. We also confirmed the association between bisphosphonates and denosumab exposure and the increased risk of these effects. 
medRxiv preprint doi: https://doi.org/10.1101/2020.06.15.20132290; this version posted June 17, 2020. The copyright holder for this preprint (which was not certified by peer review) is the author/funder, who has granted medRxiv a license to display the preprint in perpetuity. It is made available under a CC-BY-NC-ND 4.0 International license .

23

To our knowledge this is the first study that used over 12 million reports including 230 thousand osteoporosis reports from the FDA FAERS data (between 2004 and 2019) to evaluate and compare the frequency of rare adverse events associated with the use of three common osteoporosis drug types for the treatment and prevention of osteoporosis.

The risk of ONJ was significantly higher with for both bisphosphonates as a class, and denosumab when compared to teriparatide. However, the adverse effects risk related to each of individual bisphosphonate varied dramatically. Alendronate had the highest frequency of $\mathrm{ONJ}$, and ibandronate had the lowest frequency. Our findings were consistent with those from the study conducted by Zhang and colleagues[52] where they used FAERS reports from the first quarter of 2010 to the first quarter of 2014 and assessed only ibandronate and risedronate. In our study we utilized a much broader data set (2004-2019) and performed a direct pairwise comparison between alendronate, risedronate, ibandronate, zoledronic acid, and denosumab. When analyzed separately, male and female reports yielded similar results with alendronate exhibiting a nearly twofold increase in risk of AFF.

Osteoporosis patients using bisphosphonates as a class, had higher frequency of AFF when compared to denosumab, and around a hundred-fold higher value when compared to teriparatide. However, similar to the ONJ adverse effect, this difference was not preserved when individual bisphosphonates were analyzed. Patients taking risedronate and alendronate had the highest risk of AFF, while zoledronic acid had the lowest. Our study confirmed the findings of Edwards and colleagues and other studies that showed AFF risk with bisphosphonates[53-55]. There was a significantly higher risk 
medRxiv preprint doi: https://doi.org/10.1101/2020.06.15.20132290; this version posted June 17, 2020. The copyright holder for this preprint (which was not certified by peer review) is the author/funder, who has granted medRxiv a license to display the preprint in perpetuity. It is made available under a CC-BY-NC-ND 4.0 International license .

24

of AFF in females taking alendronate and risedronate, while in male patients only risedronate exhibited significant risk.

Interestingly, we observed a tentative inverse relationship of ONJ and AFF risk with frequency of administration of bisphosphonates: zoledronic acid (once a year), ibandronate (once every three months [IV], or once a month [oral]), risedronate (once a week to once a month), alendronate (once a week)[10-13]. For both side effects the trend in reporting odds ratios was similar for females and males, although in males the association was not always significant due to smaller numbers of reports.

\section{$\underline{\text { Conclusion }}$}

In our study we observed various levels of risk of ONJ and AFF adverse effects in FAERS reports of individual bisphosphonates with respect to denosumab reports. It may be beneficial to choose zoledronic acid treatment for female patients who are at risk of AFF. In patients at risk of developing ONJ, zoledronic acid may also be the safer option. However, this consideration was restricted to only two adverse effects, further research and controlled trials are needed, and health care providers should use their professional judgment and weigh all the risks and benefits to determine the best treatment option for each specific patient.

\section{Study limitations}

The FAERS reporting system is voluntary indicating that the number of reports available do not represent the number of actual cases and that adverse drug reaction frequencies 
medRxiv preprint doi: https://doi.org/10.1101/2020.06.15.20132290; this version posted June 17, 2020. The copyright holder for this preprint (which was not certified by peer review) is the author/funder, who has granted medRxiv a license to display the preprint in perpetuity. It is made available under a CC-BY-NC-ND 4.0 International license .

25

do not represent actual population incidences. A study done by Alatawi and colleagues using FAERS to found a significant underreporting of adverse events[56]. Additionally, overreporting due to newsworthiness and legal reasons may add noise to the analysis[57, 58]. Absence of comprehensive medical records and demographic variables further limits the extent of our analysis. By using the indication section in the data set, potential comorbidities were excluded, however, due to incomplete reporting, some comorbidities and concurrent medication records may be missing. Although only monotherapy reports were selected for the analysis, some concurrent and over-thecounter medications might have been underreported. That could potentially have introduced error in frequencies and reported odds ratios calculations. As with any association study, causation cannot be established based on RORs. However, analysis of over 230,000 reports provides large scale evidence for rare side effects that may go unnoticed in clinical trials or can be difficult to quantify in smaller observational studies. Despite the limitations, FAERS/AERS remains to be a unique source of population scale data used to identify and quantify rare AEs that can affect patient safety [59].

\section{Declarations}

Funding: This work was supported by University of California San Diego, Skaggs School of Pharmacy and Pharmaceutical Sciences. The funder had no role in study design, data collection and analysis, decision to publish, or preparation of the manuscript. 
medRxiv preprint doi: https://doi.org/10.1101/2020.06.15.20132290; this version posted June 17, 2020. The copyright holder for this preprint (which was not certified by peer review) is the author/funder, who has granted medRxiv a license to display the preprint in perpetuity. It is made available under a CC-BY-NC-ND 4.0 International license.

26

Competing interests: The authors have read the journal's policy and have declared that no competing interests exist.

Ethics Approval: The study used publicly available de-identified data. Institutional Review Board requirements do not apply.

Availability of data and material: Data were obtained from the FDA Adverse Event Reporting System and can be accessed at https://www.fda.gov/Drugs/GuidanceComplianceRegulatorylnformation/Surveillance/Ad verseDrugEffects/ucm082193.htm

The authors confirm that they did not have any special access privileges to these data. Code availability: Standard Unix code was used for $\$$ separated .txt file analysis Authors' contributions: T.M. and L.S.A performed the experiments. R.A. and T.M. designed the study and, R.A., L.S.A. and T.M. drafted the manuscript and reviewed the final version. R.A. processed the data set.

Acknowledgements: We thank Da Shi for contributions to processing the FAERS/AERS data files, demographic analysis, and supporting the computer environment. 
medRxiv preprint doi: https://doi.org/10.1101/2020.06.15.20132290; this version posted June 17, 2020. The copyright holder for this preprint (which was not certified by peer review) is the author/funder, who has granted medRxiv a license to display the preprint in perpetuity. It is made available under a CC-BY-NC-ND 4.0 International license .

\section{References}

1. National Osteoporosis Foundation. 2014 [cited 2019 07]; Available from: https://www.nof.org/news/54-million-americans-affected-by-osteoporosis-and-low-bone-mass 2. Raisz LG. Pathogenesis of osteoporosis: concepts, conflicts, and prospects. J Clin Invest. 2005 Dec;115(12):3318-25.

3. Song L, Xie XB, Peng LK, Yu SJ, Peng YT. Mechanism and Treatment Strategy of Osteoporosis after Transplantation. Int J Endocrinol. 2015;2015:280164.

4. Eastell R, Rosen CJ. Response to Letter to the Editor: "Pharmacological Management of Osteoporosis in Postmenopausal Women: An Endocrine Society Clinical Practice Guideline". J Clin Endocrinol Metab. 2019 Aug;104(8):3537-8.

5. Rodan GA, Fleisch HA. Bisphosphonates: mechanisms of action. J Clin Invest. 1996 Jun 15;97(12):2692-6.

6. Reszka AA, Rodan GA. Mechanism of action of bisphosphonates. Curr Osteoporos Rep. 2003 Sep;1(2):45-52.

7. Hanley DA, Adachi JD, Bell A, Brown V. Denosumab: mechanism of action and clinical outcomes. Int J Clin Pract. 2012 Dec;66(12):1139-46.

8. Reeve J. Recombinant human parathyroid hormone. BMJ. 2002 Feb;324(7335):435-6.

9. Bodenner D, Redman C, Riggs A. Teriparatide in the management of osteoporosis. Clin Interv Aging. 2007;2(4):499-507.

10. Alendronate Sodium - FDA label [cited 2019 07]; Available from:

https://www.accessdata.fda.gov/drugsatfda docs/label/2003/21575 fosomax lbl.pdf

11. Risedronate Sodium - FDA label [cited 2019 07]; Available from: mso-padding-alt:31.0pt 31.0pt 31.0pt 31.0ptmso-border-shadow:yes"> https://www.accessdata.fda.gov/drugsatfda docs/label/2015/020835s048lbl.pdf

12. Ibandronate Sodium - FDA label [cited 2019 07]; Available from: https://www.accessdata.fda.gov/drugsatfda docs/label/2016/021455s021lbl.pdf

13. Zoledronic acid- FDA label [cited 2019 07]; Available from: https://www.accessdata.fda.gov/drugsatfda docs/label/2018/021223s041lbl.pdf

14. Denosumab - FDA label [cited 2019 07]; Available from: https://www.accessdata.fda.gov/drugsatfda docs/label/2019/125320s195/bl.pdf

15. Stroup J, Kane MP, Abu-Baker AM. Teriparatide in the treatment of osteoporosis. Am J Health Syst Pharm. 2008 Mar;65(6):532-9.

16. Compston J. Pathophysiology of atypical femoral fractures and osteonecrosis of the jaw. Osteoporos Int. 2011 Dec;22(12):2951-61.

17. Aspenberg P. Denosumab and atypical femoral fractures. Acta Orthop. 2014 Feb;85(1):1. 18. Black DM, Kelly MP, Genant HK, Palermo L, Eastell R, Bucci-Rechtweg C, et al.

Bisphosphonates and fractures of the subtrochanteric or diaphyseal femur. N Engl J Med. 2010 May 13;362(19):1761-71.

19. Edwards MH, McCrae FC, Young-Min SA. Alendronate-related femoral diaphysis fracture--what should be done to predict and prevent subsequent fracture of the contralateral side? Osteoporos Int. 2010 Apr;21(4):701-3. 
medRxiv preprint doi: https://doi.org/10.1101/2020.06.15.20132290; this version posted June 17, 2020. The copyright holder for this preprint (which was not certified by peer review) is the author/funder, who has granted medRxiv a license to display the preprint in perpetuity. It is made available under a CC-BY-NC-ND 4.0 International license .

20. Koh JS, Goh SK, Png MA, Kwek EB, Howe TS. Femoral cortical stress lesions in long-term bisphosphonate therapy: a herald of impending fracture? J Orthop Trauma. 2010 Feb;24(2):7581.

21. Isaacs JD, Shidiak L, Harris IA, Szomor ZL. Femoral insufficiency fractures associated with prolonged bisphosphonate therapy. Clin Orthop Relat Res. 2010 Dec;468(12):3384-92.

22. Espey R, Grimes S, Heyburn G, Kealey WD. The first reported case of Atypical Femoral Fracture caused by daily ibandronate prescribed for bone metastases in breast cancer. BMJ Case Rep. 2017 May 9;2017.

23. Kharwadkar N, Mayne B, Lawrence JE, Khanduja V. Bisphosphonates and atypical subtrochanteric fractures of the femur. Bone Joint Res. 2017 Mar;6(3):144-53.

24. Miyakoshi N, Aizawa T, Sasaki S, Ando S, Maekawa S, Aonuma H, et al. Healing of bisphosphonate-associated atypical femoral fractures in patients with osteoporosis: a comparison between treatment with and without teriparatide. J Bone Miner Metab. 2015 Sep;33(5):553-9.

25. Koh JH, Myong JP, Jung SM, Lee J, Kwok SK, Park SH, et al. Atypical Femoral Fracture in Rheumatoid Arthritis Patients Treated With Bisphosphonates: A Nested Case-Control Study. Arthritis Rheumatol. 2016 Jan;68(1):77-82.

26. Kim YS, Park WC. Atypical subtrochanteric femur fracture in patient with metastatic breast cancer treated with zoledronic Acid. J Breast Cancer. 2012 Jun;15(2):261-4.

27. Miller PD, Pannacciulli N, Brown JP, Czerwinski E, Nedergaard BS, Bolognese MA, et al. Denosumab or Zoledronic Acid in Postmenopausal Women With Osteoporosis Previously Treated With Oral Bisphosphonates. J Clin Endocrinol Metab. 2016 Aug;101(8):3163-70.

28. Nicolatou-Galitis O, Schiodt M, Mendes RA, Ripamonti C, Hope S, Drudge-Coates L, et al. Medication-related osteonecrosis of the jaw: definition and best practice for prevention, diagnosis, and treatment. Oral Surg Oral Med Oral Pathol Oral Radiol. 2019 Feb;127(2):117-35.

29. Landesberg R, Woo V, Cremers S, Cozin M, Marolt D, Vunjak-Novakovic G, et al. Potential pathophysiological mechanisms in osteonecrosis of the jaw. Ann N Y Acad Sci. 2011 Feb;1218:62-79.

30. Aghaloo T, Hazboun R, Tetradis S. Pathophysiology of Osteonecrosis of the Jaws. Oral Maxillofac Surg Clin North Am. 2015 Nov;27(4):489-96.

31. Pazianas M, Miller P, Blumentals WA, Bernal M, Kothawala P. A review of the literature on osteonecrosis of the jaw in patients with osteoporosis treated with oral bisphosphonates: prevalence, risk factors, and clinical characteristics. Clin Ther. 2007 Aug;29(8):1548-58.

32. Paiva-Fonseca F, Santos-Silva AR, Della-Coletta R, Vargas PA, Lopes MA. Alendronateassociated osteonecrosis of the jaws: a review of the main topics. Med Oral Patol Oral Cir Bucal. 2014 Mar 1;19(2):e106-11.

33. Jan B-W, Liu H-W, Yu H, Wang S-C, Liu C-J. Alendronate-Induced Osteonecrosis of the Jaw in an Elderly Female. International Journal of Gerontology. 2012 2012/06/01/;6(2):134-6.

34. Brooks JK, Gilson AJ, Sindler AJ, Ashman SG, Schwartz KG, Nikitakis NG. Osteonecrosis of the jaws associated with use of risedronate: report of 2 new cases. Oral Surg Oral Med Oral Pathol Oral Radiol Endod. 2007 Jun;103(6):780-6.

35. Kourie HR, Antoun J, El Rassy E, Rassy M, Sader-Ghorra C, Kattan J. Osteonecrosis of the jaw during biyearly treatment with zoledronic acid for aromatase inhibitor associated bone loss in early breast cancer: A literature review. J Bone Oncol. 2015 Sep;4(3):77-9. 
medRxiv preprint doi: https://doi.org/10.1101/2020.06.15.20132290; this version posted June 17, 2020. The copyright holder for this preprint (which was not certified by peer review) is the author/funder, who has granted medRxiv a license to display the preprint in perpetuity. It is made available under a CC-BY-NC-ND 4.0 International license .

36. Haidar A, Jonler M, Folkmar TB, Lund L. Bisphosphonate (zoledronic acid)-induced osteonecrosis of the jaw. Scand J Urol Nephrol. 2009;43(6):442-4.

37. Boquete-Castro A, Gomez-Moreno G, Calvo-Guirado JL, Aguilar-Salvatierra A, DelgadoRuiz RA. Denosumab and osteonecrosis of the jaw. A systematic analysis of events reported in clinical trials. Clin Oral Implants Res. 2016 Mar;27(3):367-75.

38. Lindsay R, Krege JH, Marin F, Jin L, Stepan JJ. Teriparatide for osteoporosis: importance of the full course. Osteoporos Int. 2016 Aug;27(8):2395-410.

39. Kwon YD, Kim DY. Role of Teriparatide in Medication-Related Osteonecrosis of the Jaws (MRONJ). Dent J (Basel). 2016 Nov 9;4(4).

40. Tsuchie H, Miyakoshi N, Iba K, Kasukawa Y, Nozaka K, Dohke T, et al. The effects of teriparatide on acceleration of bone healing following atypical femoral fracture: comparison between daily and weekly administration. Osteoporos Int. 2018 Dec;29(12):2659-65.

41. Craigle V. MedWatch: The FDA Safety Information and Adverse Event Reporting Program. J Med Libr Assoc. 2007;95(2)(2):224-5.

42. Makunts $T, \cup$ A, Atayee RS, Abagyan R. Retrospective analysis reveals significant association of hypoglycemia with tramadol and methadone in contrast to other opioids. Sci Rep. 2019 Aug;9(1):12490.

43. Makunts T, Alpatty S, Lee KC, Atayee RS, Abagyan R. Proton-pump inhibitor use is associated with a broad spectrum of neurological adverse events including impaired hearing, vision, and memory. Sci Rep. 2019 Nov;9(1):17280.

44. Camacho PM, Petak SM, Binkley N, Diab DL, Eldeiry LS, Farooki A, et al. AMERICAN ASSOCIATION OF CLINICAL ENDOCRINOLOGISTS/AMERICAN COLLEGE OF ENDOCRINOLOGY CLINICAL PRACTICE GUIDELINES FOR THE DIAGNOSIS AND TREATMENT OF POSTMENOPAUSAL OSTEOPOROSIS- 2020 UPDATE. Endocr Pract. 2020 May;26(5):564-70.

45. Eastell R, Rosen CJ, Black DM, Cheung AM, Murad MH, Shoback D. Pharmacological Management of Osteoporosis in Postmenopausal Women: An Endocrine Society* Clinical Practice Guideline. J Clin Endocrinol Metab. 2019 05;104(5):1595-622.

46. Jeremiah MP, Unwin BK, Greenawald MH, Casiano VE. Diagnosis and Management of Osteoporosis. Am Fam Physician. 2015 Aug;92(4):261-8.

47. Cosman F, de Beur SJ, LeBoff MS, Lewiecki EM, Tanner B, Randall S, et al. Clinician's Guide to Prevention and Treatment of Osteoporosis. Osteoporos Int. 2014 Oct;25(10):2359-81. 48. Management of osteoporosis in postmenopausal women: 2010 position statement of The North American Menopause Society. Menopause. 20102010 Jan-Feb;17(1):25-54; quiz 5-6. 49. Raschi E, Mazzarella A, Antonazzo IC, Bendinelli N, Forcesi E, Tuccori M, et al. Toxicities with Immune Checkpoint Inhibitors: Emerging Priorities From Disproportionality Analysis of the FDA Adverse Event Reporting System. Target Oncol. 2019 04;14(2):205-21.

50. Aldea Perona A, García-Sáiz M, Sanz Álvarez E. Psychiatric Disorders and Montelukast in Children: A Disproportionality Analysis of the VigiBase $\left({ }^{\circledR}\right)$. Drug Saf. 2016 Jan;39(1):69-78.

51. Böhm R. Primer on Disproportionality Analysis. Semantic Scholar; 2018.

52. Zhang X, Hamadeh IS, Song S, Katz J, Moreb JS, Langaee TY, et al. Osteonecrosis of the Jaw in the United States Food and Drug Administration's Adverse Event Reporting System (FAERS). J Bone Miner Res. 2016 Feb;31(2):336-40.

53. Edwards BJ, Bunta AD, Lane J, Odvina C, Rao DS, Raisch DW, et al. Bisphosphonates and nonhealing femoral fractures: analysis of the FDA Adverse Event Reporting System (FAERS) and 
medRxiv preprint doi: https://doi.org/10.1101/2020.06.15.20132290; this version posted June 17, 2020. The copyright holder for this preprint (which was not certified by peer review) is the author/funder, who has granted medRxiv a license to display the preprint in perpetuity. It is made available under a CC-BY-NC-ND 4.0 International license.

30

international safety efforts: a systematic review from the Research on Adverse Drug Events And Reports (RADAR) project. J Bone Joint Surg Am. 2013 Feb 20;95(4):297-307.

54. Selga J, Nunez JH, Minguell J, Lalanza M, Garrido M. Simultaneous bilateral atypical femoral fracture in a patient receiving denosumab: case report and literature review.

Osteoporos Int. 2016 Feb;27(2):827-32.

55. Ramchand SK, Chiang CY, Zebaze RM, Seeman E. Recurrence of bilateral atypical femoral fractures associated with the sequential use of teriparatide and denosumab: a case report. Osteoporos Int. 2016 Feb;27(2):821-5.

56. Alatawi YM, Hansen RA. Empirical estimation of under-reporting in the U.S. Food and Drug Administration Adverse Event Reporting System (FAERS). Expert Opin Drug Saf. 2017 Jul;16(7):761-7.

57. Maciejewski M, Lounkine E, Whitebread S, Farmer P, DuMouchel W, Shoichet BK, et al. Reverse translation of adverse event reports paves the way for de-risking preclinical off-targets. Elife. 2017 Aug 8;6.

58. Michel C, Scosyrev E, Petrin M, Schmouder R. Can Disproportionality Analysis of Postmarketing Case Reports be Used for Comparison of Drug Safety Profiles? Clin Drug Investig. 2017 May;37(5):415-22.

59. Hauben M, Madigan D, Gerrits CM, Walsh L, Van Puijenbroek EP. The role of data mining in pharmacovigilance. Expert Opin Drug Saf. 2005 Sep;4(5):929-48. 
FAERS adverse reaction reports

$$
(n=12,004,552)
$$

Selection of osteoporosis indication reports

$$
(n=232,512)
$$

Selection of osteoporosis only indication reports

$$
(n=133,089)
$$

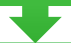

Selection of denosumab, bisphosphonate (alendronate, risedronate, ibandronate, and zoledronic acid) and teriparatide reports

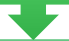

Bisphosphonates $(n=36,527)$, denosumab $(n=18,336)$

vs

teriparatide $(n=66,173)$

Frequency calculations and reporting odds ratio analysis

Selection of individual bisphosphonate cohorts

\section{$\checkmark$}

alendronate $(n=14,682)$ ibandronate $(n=6,065)$ risedronate $(n=2,309)$ zoledronic acid $(n=13,471)$

vs

denosumab $(n=18,336)$

Frequency calculations and reporting odds ratio analysis

Selcetion of reports into male and female cohorts for subgroup analysis

Frequency calculations and reporting odds ratio analysis 
Frequency of osteonecrosis of jaw (ONJ) reports in patients with osteoporosis in bishosphonate, denosumab, and teriparatide cohorts

bisphosphonates

온

denosumab

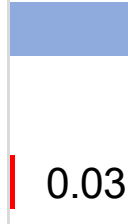

0.00

1.00

2.00

3.00

4.00

Frequency (\%)

b

Reporting odds ratios of ONJ reports in the bisphosphonate and denosumab cohorts when compared to the teriparatide cohort

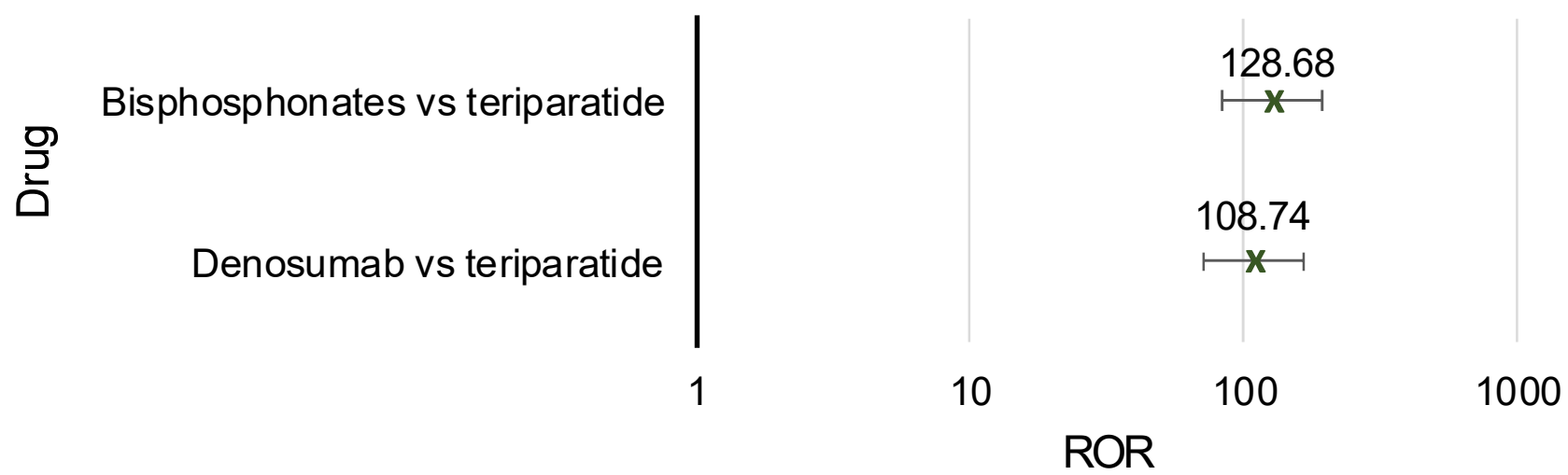



osteoporosis in bishosphonate and denosumab cohorts

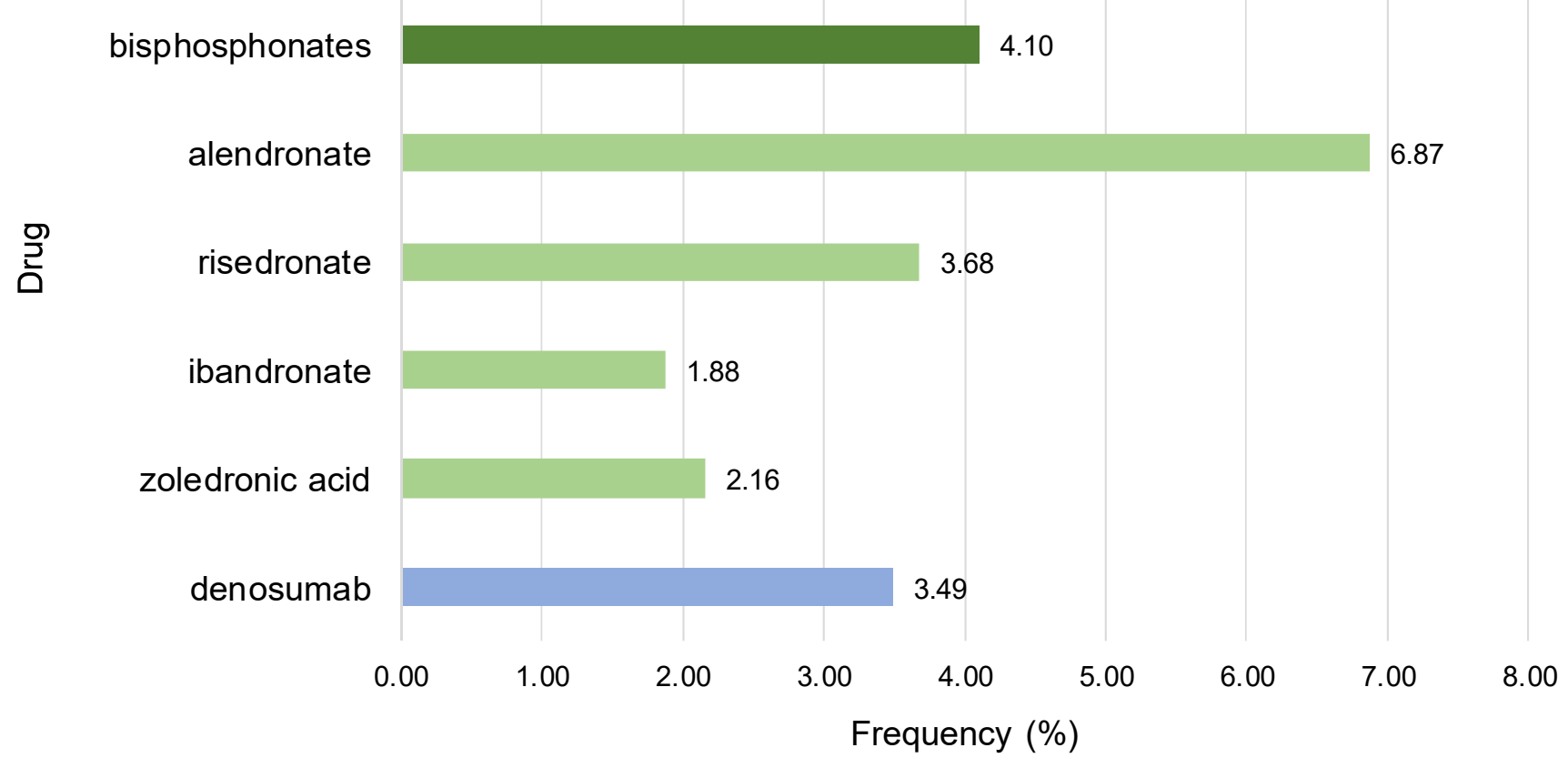

b Reporting odds ratios of ONJ reports in the bisphosphonate cohorts when compared to the denosumab cohort

bisphosphonates vs denosumab

alendronate vs denosumab
온

ibandronate vs denosumab

zoledronate vs denosumab

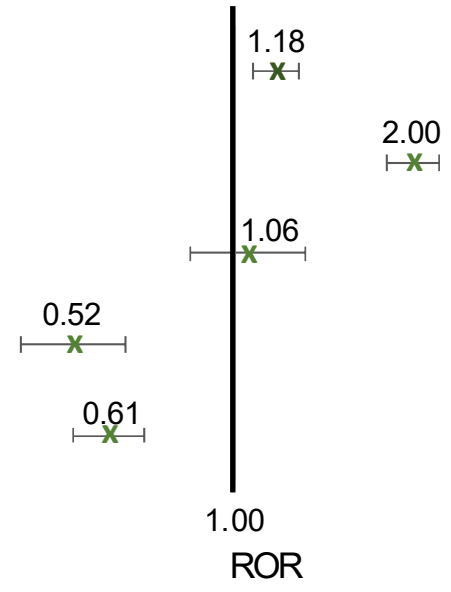


a Frequency of osteonecrosis of jaw (ONJ) reports in female patients with osteoporosis in bishosphonate and denosumab cohorts

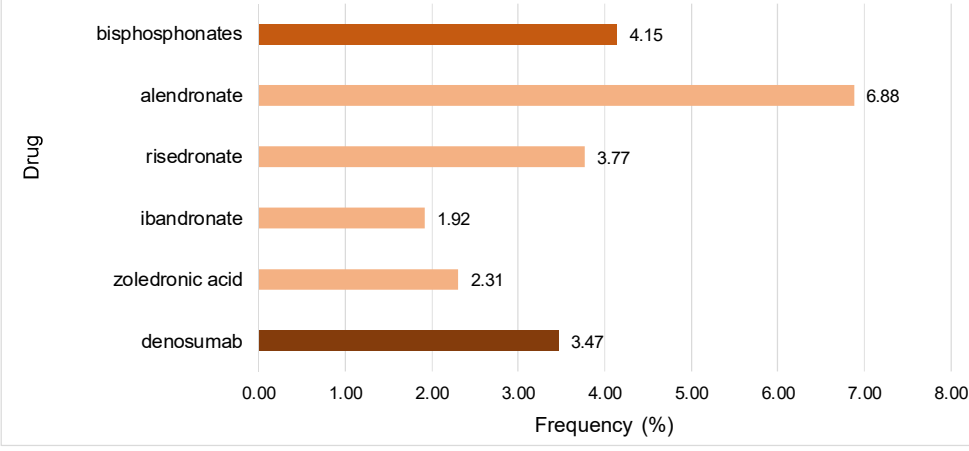

b Reporting odds ratios of ONJ reports in the bisphosphonate female cohorts when compared to the female denosumab cohort

bisphosphonates vs denosumab

alendronate vs denosumab

?ำ

risedronate vs denosumab

ibandronate vs denosumab

zoledronate vs denosumab

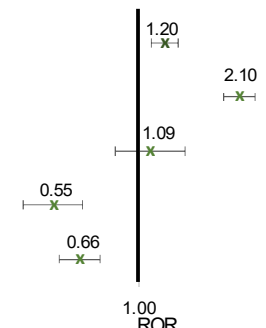

ROR
Frequency of osteonecrosis of jaw (ONJ) reports in male patients with osteoporosis in bishosphonate and denosumab cohorts

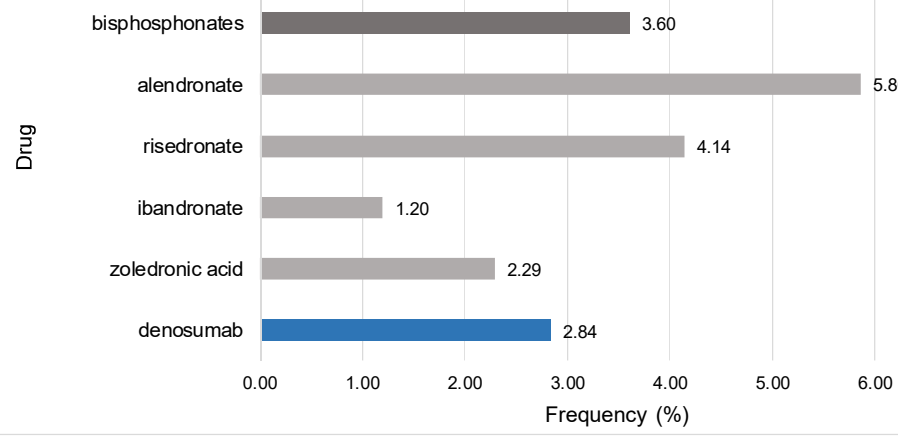

d Reporting odds ratios of ONJ reports in the male bisphosphonate cohorts when compared to the male denosumab cohort

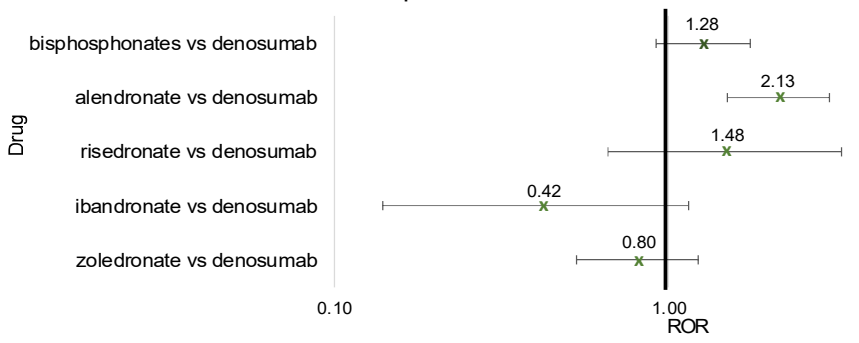


Frequency of atypical femur fracture (AFF) reports in patients with osteoporosis in bisphosphonate, denosumab, and teriparatide cohorts

bisphosphonates

온

denosumab

teriparatide | 0.01

$0.00 \quad 0.20$

0.40

0.60

0.80

1.00

Frequency

$(\%)$

b

Reporting odds ratios of AFF reports in the bisphosphonate and denosumab cohorts when compared to the teriparatide cohort

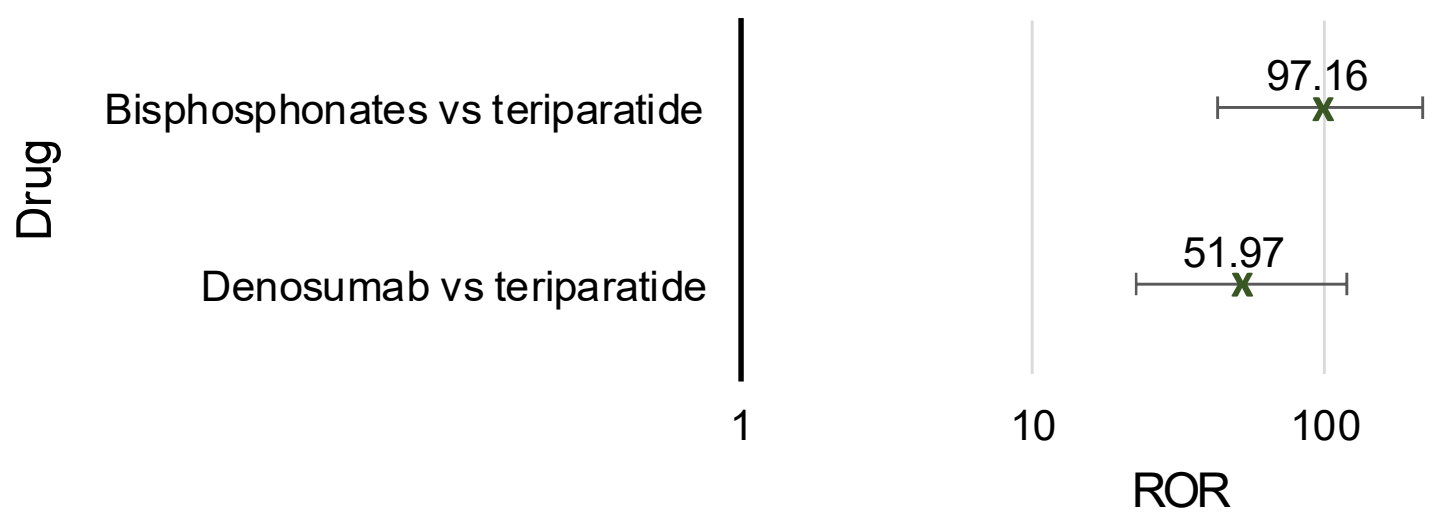


a

Frequency of atypical femur fracture (AFF) reports in patients with osteoporosis in bisphosphonate and denosumab cohorts

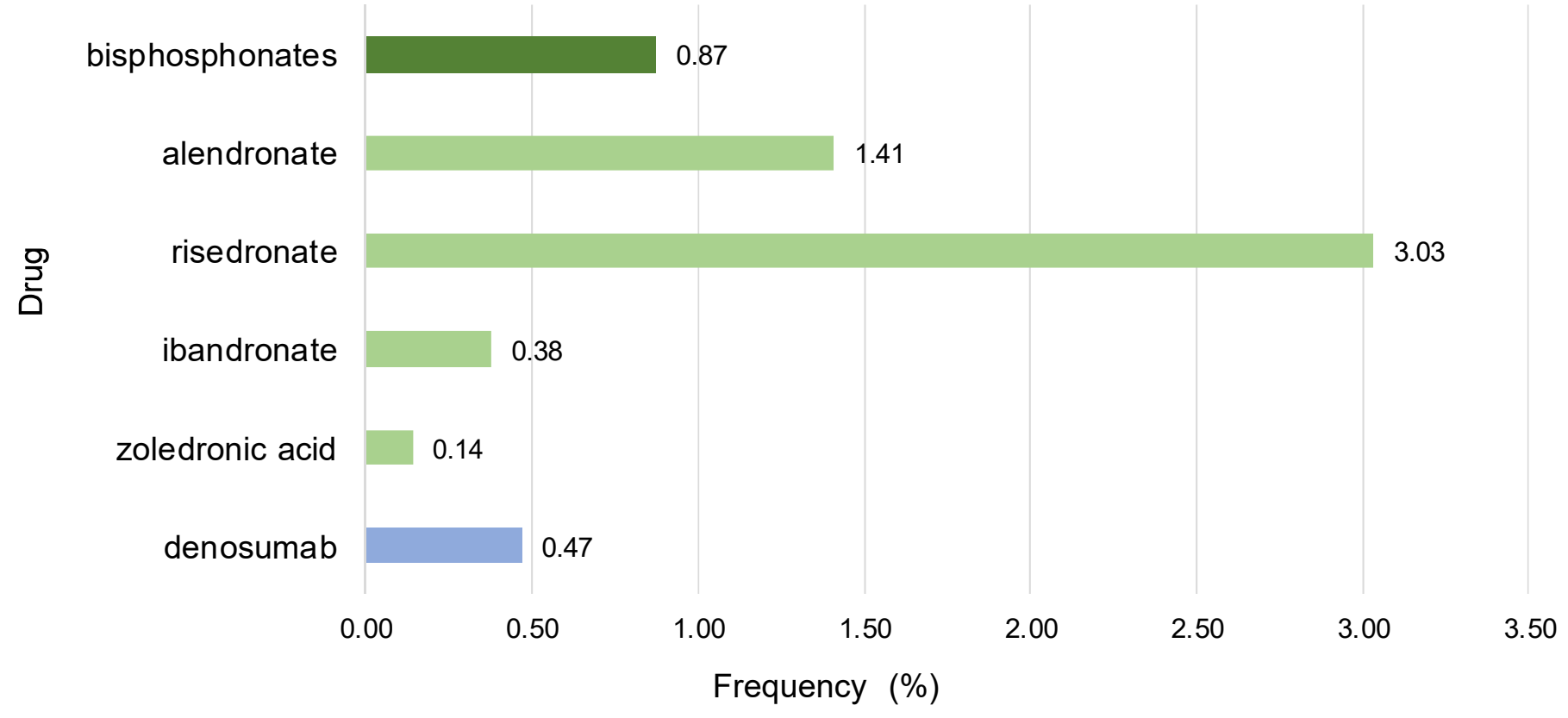

b Reporting odds ratios of AFF reports in the bisphosphonate cohorts when compared to the denosumab cohort

bisphosphonates denosumab

alendronate vs denosumab

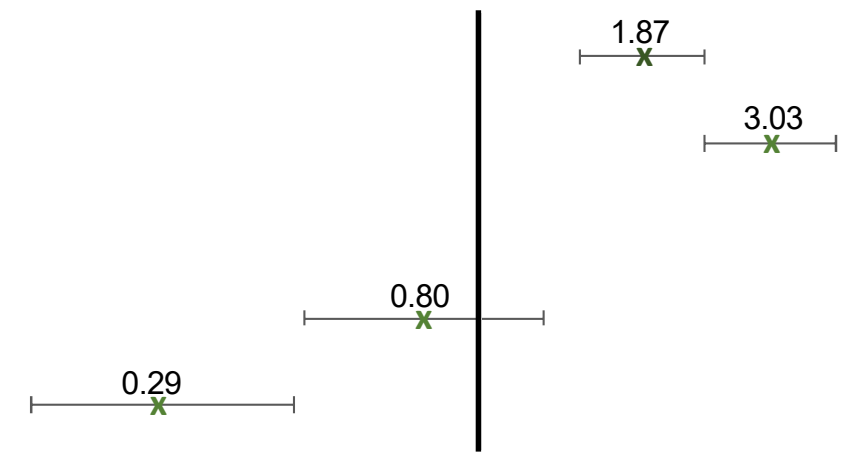

1.87

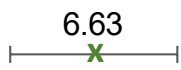

올 risedronate vs denosumab

ibandronate vs denosumab

zoledronate vs denosumab 
a Frequency of atypical femur fracture (AFF) reports in female patients with osteoporosis in bisphosphonate and denosumab cohorts

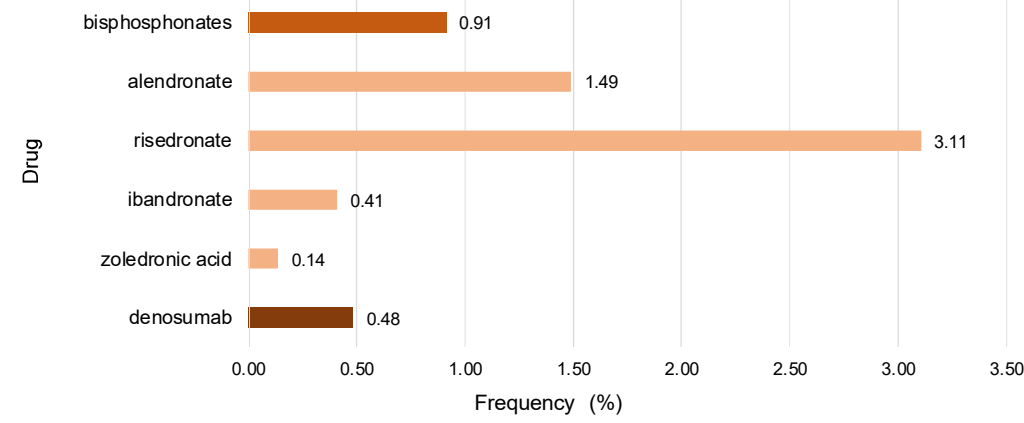

b Reporting odds ratios of AFF reports in the bisphosphonate female cohorts when compared to the female denosumab cohort

bisphosphonates vs denosumab

alendronte vs denosumab

곤 risedronate vs denosumab

ibandronate vs denosumab

zoledronate vs denosumab

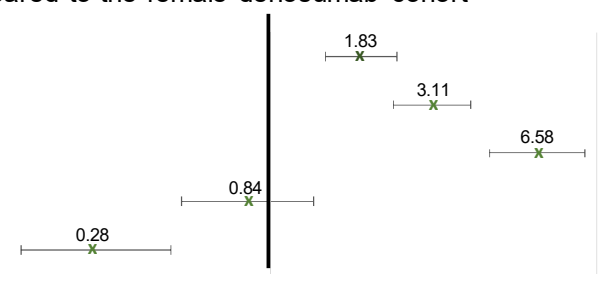

C

Frequency of atypical femur fracture (AFF) reports in male patients with osteoporosis in bisphosphonate and denosumab cohorts

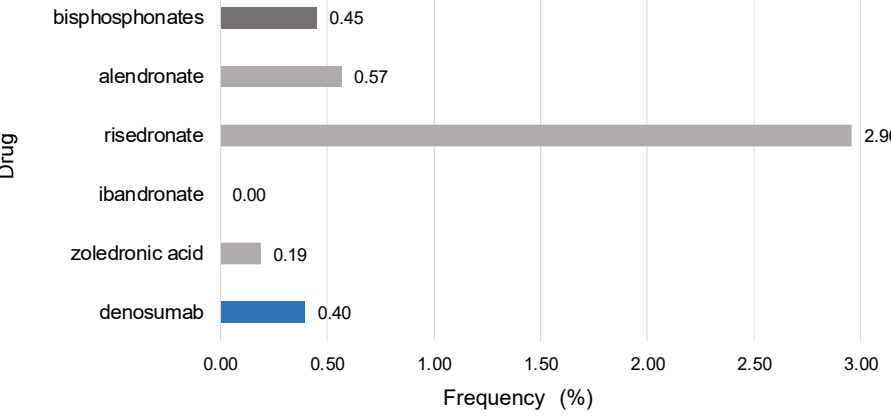

d Reporting odds ratios of AFF reports in the male bisphosphonate cohorts when compared to the male denosumab cohort
bisphosphonates denosumab
alendronate vs denosumab
号 $r$
risedronate vs denosumab
ibandronate vs denosumab
zoledronate vs denosumab

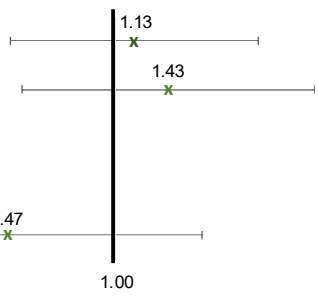

0.10 